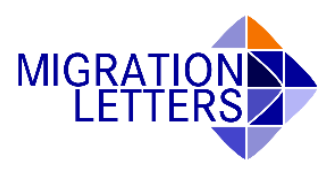

First Submitted: 20 May 2019 Accepted: 26 December 2019

DOI: https://doi.org/10.33182/ml.v17i1.901

\title{
Introduction to the Special Issue: Politics, Policies and Diplomacy of Diaspora Governance: New Directions in Theory and Research
}

\author{
Bahar Baser Ozturk ${ }^{1}$ and Henio Hoyo ${ }^{2}$
}

\begin{abstract}
This special issue entitled "Politics, Policies and Diplomacy of Diaspora Governance: New Directions in Theory and Research" is a result of a workshop organised by Dr Bahar Baser (Coventry University, UK) and Dr Henio Hoyo (CIDE and UDEM, Mexico) at the Freud Museum on December 6, 2018, and funded by the British Academy / Newton Mobility Grant. Throughout the workshop, diaspora scholars from various fields explored diaspora politics and policies from a variety of perspectives with a special focus on home state policies towards mobilising diasporas. A central theme that has emerged throughout the discussions was the ascending importance of diasporas as non-state actors in international relations and the multifaceted relationships they form with their home and host states as well as other non-governmental organisations. The special issue contains case studies from different parts of the world, from Latin America to the Balkans, from Africa to the Middle East, revealing that there is a growing global trend of engaging diasporas to complex policy mechanisms at home and abroad.
\end{abstract}

Keywords: politics; policies; diplomacy; diaspora; governance.

\section{Introduction}

This special issue entitled "Politics, Policies and Diplomacy of Diaspora Governance: New Directions in Theory and Research" is a result of a workshop organised by Dr Bahar Baser (Coventry University, UK) and Dr Henio Hoyo (CIDE and UDEM, Mexico) at the Freud Museum on 6 December 2018 and funded by the British Academy / Newton Mobility Grant (NMG2R2\100111). The grant was awarded to a project entitled "Scrutinising Home States and Diaspora Governance: A Comparative Perspective on Turkey and Mexico in Theory and Practice", which aimed at comparing and contrasting Mexican and Turkish diaspora governance politics through a critical lens. This comparison also allowed the investigators of the project to push the boundaries in contemporary debates on state-led diaspora mobilisation and contribute to theorising such policies by drawing from a broader literature in international relations. The workshop was part of that effort; in other words, the investigators wanted to start a conversation revolving around diaspora governance but also open to floor to wider discussions surrounding the importance of diasporas in world politics. The organisers suggested that new directions in theory and research are needed and interactions among scholars who work on different case studies from different

\footnotetext{
${ }^{1}$ Dr Bahar Baser Ozturk, Senior Research Fellow, Coventry University, United Kingdom. E-mail: bahar.baser@gmail.com.

${ }^{2}$ Dr Henio Hoyo, Centro de Investigación y Docencia Económicas (CIDE) and University of Monterrey (UDEM), Mexico City, Mexico. E-mail: henio_hp@yahoo.com.mx.

Acknowledgement: We would like to thank the British Academy / Newton Mobility Grant (NMG2R2 $\backslash 100111)$ for funding our research on which this special issue draws upon.
} 


\section{Politics, Policies and Diplomacy of Diaspora Governance}

perspectives can represent a valuable space of interdisciplinary connection to move the field forward.

The institutional or factual relationships between home states and their emigrants have always existed, at least in the traditional form of consular protection, or in very specific areas, such as the economy (i.e. remittances). However, the last decades have witnessed a large expansion of institutions, policies, and other state-sponsored mechanisms all around the globe, linking home states and emigrants/diasporas well beyond the traditional areas. In many cases, such diaspora engagement policies and institutions have been devised by home states with the implicit or explicit goal of better control, according to fields such as national/political interests, the social, economic, cultural and political activities of their diasporas. In this way, more than a hundred states have established forms of diaspora engagement policies and institutions, with a variety of motivations (Gamlen, Cummings, and Vaaler, 2019).

During the last decades, academics have been trying to understand and interpret the mechanisms behind home states' policies on outreach to their citizens abroad. A growing body of literature has been dedicated to this emerging phenomenon of the development of diasporaengagement policies cultivated by political actors in the homeland (Adamson, 2006; Bauböck, 2003; Brand, 2006; Brinkerhoff, 2005; Collyer, 2014; Fitzgerald 2009; Gamlen, 2006; De Haas, 2007; Mügge, 2012; Ragazzi, 2014, 2009; Varadarajan, 2010). This literature focused on a variety of topics including unpacking the terms "state" and "diaspora" to start with (Brubaker, 2005; Délano and Mylonas, 2019), the evolution of diaspora engagement policies through time (Délano, 2011; Mencutek and Baser, 2018), and the multi-tiered nature of diaspora engagement policies (Han, 2019; Pedroza and Palop-García, 2017) among others. Many other specialists have studied specific areas of diaspora-engagement policies, not only including economics and migration/citizenship, but also other topics such as specific extraterritorial security measures by authoritarian and semiauthoritarian states (Brinkerhoff, 2005; Glasius, 2018). Theorising sending states' motivations and their involvement in shaping, mobilising and in some cases "taming" the diaspora will continue as more empirical studies emerge that endeavour to provide deeper analysis that goes beyond explanations solely focusing on economic interests.

Throughout the workshop, diaspora scholars from various fields explored diaspora politics and policies from a variety of perspectives including international relations, sociology, anthropology, history and peace and conflict studies, with a special focus on home state policies towards mobilising diasporas. Central themes that have emerged throughout the discussions were the ascending importance of diasporas as non-state actors in international relations and the multifaceted relationships they form with their home and host states as well as other non-governmental organisations. A particular contribution of this special issue is its demonstration of diaspora agency in the triadic relationship among home and host states and diasporas. Only a set of articles presented at the workshop are included in this special issue, which contains case studies from different parts of the world, from Latin America to the Balkans, from Africa to the Middle East, revealing that there is a growing global trend of engaging diasporas to complex policy mechanisms at home and abroad. The workshop also created a network for early career, mid-career and senior scholars to exchange ideas and continue these discussions forward. The British Academy / Newton project, overall, strengthened relations between the University of Monterrey and Coventry University and paved the way for long-term collaborations. 
The special issue reflects the diversity of approaches that can be applied to the study of diasporas and the fruitful debates and comparisons that can be made between seemingly very different cases across the globe. Also, the contributions here reflect the different actors involved in diaspora governance: from academics and practitioners to civil society representatives, to artists.

Amjad Mohamed Saleem's article focuses on the role of the Sri Lankan diasporas in peace and reconciliation efforts in their homeland. As a practitioner and academic himself, Saleem adapts lessons learnt approach from his hands-on experience while he was working with the International Alert. He emphasises the importance of trust-building measures and gaining the confidence of the parties even in diaspora engagement strategies in peacebuilding as diasporas have the potential to become salient actors in peace processes. His findings show that although there is potential, without vertical relationships between diaspora actors and positive horizontal relations with the home state, diasporas' potential can be wasted in peacebuilding efforts.

Balca Arda's article focuses on diasporas in the making and analyses "the imagery of precarious class through the narration of refugee journeys in Turkey through two different movies with an emphasis on the visuality of cinematic narration". Balca, as an artist and an academic herself, uses a blended narrative and approaches diaspora politics, issues of identity and sense-ofbelonging, home-making in the host country from the perspective of refugee arts. Her article urges the readers to understand refugee experiences not from a perspective of pity, but from the human conditions of politics of justice.

Elise Feron's contribution is on diaspora politics, with a specific focus on conflict-generated diasporas. Feron invites the readers to understand diaspora politics as a co-construction between a series of actors that are not limited to home and host states. Pushing the boundaries of the current literature, Feron theorises diaspora mobilisation through vertical interactions among different diaspora groups and transnational networks that go beyond home and host state corridors of engagement. Therefore, her article shifts the focus from a state-centred perspective to a much wider understanding of diasporas as transnational actors that move across levels of and spheres of engagement.

Antonio Alejo's article focuses in the activism of migrants as a form of diplomacy, which is influenced not only by the relations between the states of origin and destination but also (and most importantly) by the circumstances that migrants faced within those countries. He applies processtracing methodology in the study of CEDES, a binational organisation in Mexico City that works with returning migrants. He finds that bi-national organisations adopt an array of strategies not only to help migrants to maintain links with the US and the communities they just to live, but also to facilitate their (re)incorporation to Mexico, using a form of post-national thinking that makes the bi-national experience an asset, and not a hindrance.

Mari Toivanen and Bahar Baser's article also focuses on diasporas' increasing role in peace and conflict in their homelands. By challenging the peace-makers / peace-wreckers paradigm, they categorise the multiple roles that diasporas can play during the course of a conflict and in postconflict phases, considering the hybrid nature of diasporas and their shifting stances by time. The article specifically contributes to two emerging discussions in this field: the role of the second generation and intra-diaspora relations which are usually overlooked in the diaspora studies literature that approaches the issue from a peace and conflict studies perspective. 


\section{Politics, Policies and Diplomacy of Diaspora Governance}

Ahmet Erdi Ozturk and Hakki Tas' article takes recent migration flows as a case study and focuses on extraterritorial repression exercised by home states to suppress dissident populations in exile outside the state borders. Building on a newly emerging literature on transnational authoritarianism, the authors categorise the repertoires of transnational repression strategies that the Turkish ruling elite is using to tame and exterminate the Gulen Movement which is accused of contemplating the aborted coup in 2016. The article is a welcome addition to the diaspora governance studies literature, which tended to focus more on the economic and cultural side of stateled diaspora management strategies. Their findings might shed light on other case studies on authoritarian regimes.

Kennedy Ebang Nijkang's article develops a critical approach towards state-led diaspora governance and investigates the role of leadership and the persuasiveness of diaspora policies for the diaspora populations themselves. Nijkang adopts a rhetorical analysis of multi-case data and compares Ethiopia's and Kenya's state-diaspora policy documents to understand how these states' perception of their diasporas share their mobilisation strategies. Nijkang concludes that while formulating such policies states include certain groups while segregating others depending on how they construct the "nation".

Hakan Sandal's article focuses on the Kurdish Diaspora in the UK and specifically examines the ways in which London's queer Kurdish activists imagine Kurdistan(s) and their relation to politics surrounding the Kurdish and queer struggles in the United Kingdom. The article's merit is that it looks at both homeland and hostland oriented activism from an anthropological perspective. By doing that, Sandal draws attention to a "radical queer epistemic network" that establishes a transnational link among/across different borders of queer communities in the UK such as race and class; between "homeland" and "hostland"; and the present and the future. This article is a welcome addition to previous work on Kurdish diaspora in the UK which severely ignored queer perspectives. The findings of this article are also extremely relevant for other queer Middle Eastern diasporas in the UK and beyond.

Dani Kranz studies the Israeli-Jewish diaspora in Germany. She narrates how the diaspora policies of Israel have not been driven by the goal of creating enduring bonds with citizens abroad; this, mostly because in contrast to the strong promotion of immigration of Jews to Israel, the emigration of Jews from Israel has been historically met with resistance and even stigmatisation. In turn, Israeli diasporas tend to be not only very engaged in Israeli politics, but also notoriously critical of it - but this without renouncing, neither to their Jewish identity (expressed through the creation of formal and informal organisations) nor to their emotional attachment to the land. Precisely, the new Israeli policies aim to take these complex relationships as the basis of a new relation, aiming to promote the 'love for the State of Israel' among the diaspora.

Jasmin Hazic and Dzeneta Karabegovic's article is an original contribution as it goes beyond the discussions on diaspora activities on the ground and focuses on digital activism during wartime. By building on discussions on digital diaspora diplomacy, they investigate BOSNET, an online epistemic community of Bosnian diaspora IT pioneers, and activism surrounding BOSNET when the internet was relatively new and when diplomatic channels were limited during the war. Hazic and Karabegovic demonstrate the readers the importance of diaspora agency in times of war and conflict and that diaspora diplomacy is not a completely new phenomenon. This article is an excellent contribution to the literature on digital activism on diasporas as well as diaspora contributions to peace and conflict. 
Firat Yaldiz's article is a welcome contribution to the literature on Turkish diaspora. The author draws attention to how states define the very concept of diaspora before even engaging in formulating diaspora management policies. He clearly demonstrates the problematic nature of stateinitiated definitions where ambiguity might bring less clarity to the state's aims of engaging with citizens abroad. In the case of Turkey, who is considered as a member of Turkish diaspora remains unclear because the state discourse involves concepts such as related communities, Ottoman residues, all Muslims (Ummah) and even international students.

Zeynep Sahin Mencutek contributes with a pioneering article on the diasporisation process of the Syrian Refugees and explores the emerging transnational activities and capabilities of the refugee community. Her findings rely on extensive qualitative data drawn from interviews in Şanlıurfa, a border province in south-eastern Turkey which hosts a half-million Syrians. SahinMencutek explores level of individual engagements at the micro-level in the forms of connecting with relatives, short visits to the hometowns, and remitting and at the grassroots level where there have been mixed engagement initiatives Syrians with higher economic capital and secured legal status form some economic, political, and cultural institutional channels more focusing on empowerment and solidarity in the host country and some plans for the post-conflict reconstruction in Syria. She concludes that Syrian refugees' activities are limited due to the lack of political and economic security in the host country as well as no prospect for the stability in the home country.

Luicy Pedroza and Pau Palop-García focus on an understudied aspect of diaspora policies: the role of migrant consultative bodies. They provide an overview of the development of such bodies in Latin America and the Caribbean and make the point for differentiating those located at the national government structures, from those at the consular level - as this greatly affects the issues and audiences they are focused on. Next, the authors propose a typology based in two factors: the degree of independence of the body from national governments, and the degree of entitlement they enjoy. They find that consultative bodies are increasingly used in the region, but their characteristics and impact vary greatly across the cases. Three groups are identified low entitlement and low independence; low independence but moderate to high independence, and both higher entitlement and independence. The authors end by inviting researchers to study in more depth the factors that explain such variations.

Finally, Pablo Mateos focuses on a major paradox: in some cases, emigrants can enjoy better access to rights and governmental services by remaining abroad, than by returning to their country of origin. In his study, he first presents the radical change in Mexican policies regarding its diasporas: from cold and restrictive, to granting them a series of key rights (e.g. external voting and dual citizenship) as well as better consular services. Nevertheless, as the author explains, the same reforms have not been implemented in Mexico itself, so communities like returning migrants and foreign-born citizens face complex bureaucratic challenges that seriously limit, or even preclude them from having access to basic rights and services, like education. This is further aggravated by discrimination from both social actor and authorities. He, therefore, calls for symmetrical diaspora rights, where return migrants can find an institutional and social environment that helps them to integrate to the Mexican society.

Together, all these articles present that the diaspora engagement policies and politics are more complex than what is visible to the outside world. The way that state-led governance policies are formulated, diaspora grassroots repertoires of action are formed, and the host country opportunity structures are created depend on a variety of factors and interest/will/agenda of multiple actors that 


\section{Politics, Policies and Diplomacy of Diaspora Governance}

go beyond the state-centric perspectives and previous perceptions which depicted diasporas as passive receivers of state policies. The special issue raises central questions regarding the role of diasporas in peace and conflict mechanisms, diasporas' agency in policy formulations, multifaceted agendas of state-led diaspora governance initiatives, transnational activities of refugees who can be considered as diasporas in the making.

\section{References}

Adamson, F. B. (2006). “Crossing Borders: International Migration and National Security.” International Security 31(1): 165-99. https://doi.org/10.1162/isec.2006.31.1.165.

Bauböck, R. (2003). “Towards a Political Theory of Migrant Transnationalism.” International Migration Review 37(3): 700-723. http://doi.wiley.com/10.1111/j.1747-7379.2003.tb00155.x.

Brand, L. A. (2006). Citizens Abroad: Emigration and the State in the Middle East and North Africa. Cambridge: Cambridge University Press.

Brinkerhoff, J. M. (2005). "Digital Diasporas and Governance in Semi-Authoritarian States: The Case of the Egyptian Copts." Public Administration and Development 25(3): 193-204. https://doi.org/10.1002/pad.364.

Brubaker, R. (2005). "The 'Diaspora' Diaspora." Ethnic and Racial Studies 28(1): 1-19. http://www.informaworld. com/10.1080/0141987042000289997.

Collyer, M. (2014). Emigration Nations: Policies and Ideologies of Emigrant Engagement. Houndmills - New York: Palgrave Macmillan.

Délano, A. (2011). Mexico and Its Diaspora in the United States: Policies of Emigration since 1848. New York: Cambridge University Press.

Délano, A., and H. Mylonas (2019). "The Microfoundations of Diaspora Politics: Unpacking the State and Disaggregating the Diaspora." Journal of Ethnic and Migration Studies 45(4): 473-91. https://doi.org/10.1080/1369183X. 2017.1409160.

Fitzgerald, D. (2009). A Nation of Emigrants: How Mexico Manages Its Migration. Berkeley: University of California Press.

Gamlen, A. (2006). COMPAS Working Papers Diaspora Engagement Policies: What Are They, and What Kinds of States Use Them? Oxford. https://www.compas.ox.ac.uk/wp-content/uploads/WP-2006-032-Gamlen_Diaspora Engagement Policies.pdf.

Gamlen, A., M.E. Cummings, and P.M. Vaaler (2019). "Explaining the Rise of Diaspora Institutions." Journal of Ethnic and Migration Studies 45(4): 492-516. https://doi.org/10.1080/1369183X.2017.1409163.

Glasius, M. (2018). "Extraterritorial Authoritarian Practices: A Framework." Globalizations 15(2): 179-97. https://doi.org/10.1080/14747731.2017.1403781.

De Haas, H. (2007). "Turning the Tide? Why Development Will Not Stop Migration.” Development and Change 38(5): 819-41. https://doi.org/10.1111/j.1467-7660.2007.00435.x.

Han, E. (2019). "Bifurcated Homeland and Diaspora Politics in China and Taiwan towards the Overseas Chinese in Southeast Asia." Journal of Ethnic and Migration Studies 45(4): 577-94. https://doi.org/10.1080/1369183X. 2017.1409172.

Mencutek, Z.S., and B. Baser (2018). "Mobilizing Diasporas: Insights from Turkey's Attempts to Reach Turkish Citizens Abroad." Journal of Balkan and Near Eastern Studies 20(1): 86-105. https://doi.org/10.1080/19448953. 2017.1375269.

Mügge, L. (2012). "Dual Nationality and Transnational Politics.” Journal of Ethnic and Migration Studies 38(1): 1-19. https://doi.org/10.1080/1369183X.2012.640003.

Pedroza, L., and P. Palop-García (2017). "The Grey Area between Nationality and Citizenship: An Analysis of External Citizenship Policies in Latin America and the Caribbean." Citizenship Studies 21(5): 587-605. http://dx.doi.org/10.1080/13621025.2017.1316701.

Ragazzi, F. (2009). "Governing Diasporas.” International Political Sociology 3(4): 378-97. https://doi.org/10.1111/ j.1749-5687.2009.00082.x.

Ragazzi, F. (2014). "A Comparative Analysis of Diaspora Policies.” Political Geography 41: 74-89. http://www. sciencedirect.com/science/article/pii/S0962629814000043.

Varadarajan, L. (2010). The Domestic Abroad: Diasporas in International Relations. Oxford - New York: Oxford University Press. 